\title{
Blended Learning Integrated Fieldwork on Fundamentals of Geology Learning During the Covid-19 Pandemic
}

\author{
https://doi.org/10.3991/ijet.v16i07.21213 \\ Dwi Angga Oktavianto ${ }^{(凶)}$, Sumarmi, Sugeng Utaya, \\ Didik Taryana \\ Universitas Negeri Malang, Malang, Indonesia \\ dwi.angga.2007219@students.um.ac.id
}

\begin{abstract}
The purpose of this research was to test the blended learning integrated fieldwork in the Fundamentals of Geology learning. Classroom Action Research (CAR) was used in this study. The research subjects consisted of 32 Grade 10 Mining Geology students of SMK Negeri 1 Binuang in the 2019/2020 academic year. Data analysis was carried out using quantitative descriptive analysis, namely by observing the research data which was then followed by synthesis using a literature review. From the results of research during the Pre-Cycle, it was known that the number of students who met the Minimum Completeness Criteria (KKM) was $18.75 \%$, while in Cycle I it is $84.374 \%$, and Cycle II was $77.78 \%$. These results indicated that there was an increase from Pre-Cycle to Cycle I, but there was a decrease in Cycle I to Cycle II. The results obtained in this CAR showed that blended learning integrated fieldwork has the potential to be effective as a learning model for the Fundamentals of Geology during the COVID-19 Pandemic. Some things that need to be considered so that blended learning integrated fieldwork can be effective in learning is by paying attention to scientific steps during learning, choosing fieldwork locations that are accessible to accessibility and there are communication and internet signals, as well as intensive guidance from the teacher. Regarding the COVID-19 Pandemic, it is also necessary to design integrated blended learning fieldwork that complies with health protocols.
\end{abstract}

Keywords-Fieldwork, Blended learning, Fundamentals of Geology, COVID19

\section{Introduction}

The COVID-19 Pandemic has forced the world to adapt to a new normal. The world of education, in this case the learning process in schools, also includes those that must change [1]-[3]. The big challenge for teachers in this regard is that they have to keep trying to deliver quality learning during the pandemic period [4]. As the vanguard in preparing, implementing and evaluating learning, teachers are required to always be 
innovative and creative [5]. One way that many have taken is through online learning [6]-[9].

Online learning has become a new habit during this Pandemic. The transition from traditional learning to online learning due to the COVID-19 Pandemic has the potential to succeed [10], [11]. The learning preparation and assessment process carried out with a new format due to the COVID-19 Pandemic needs to be carefully structured in order to achieve successful learning [12]. For example, tests in open book mode during faceto-face learning are not popular, but during online learning, the method will become a new habit that teachers should pay attention to [13], [14]. Apart from that, the unequal internet signal and the many other challenges in providing quality online learning must also be handled properly.

Online learning problems are not only related to planning and assessment of learning, but on the other hand, students often have problems with discipline, limited mastery of the material, and an environment (home) that is not conducive to online learning [7]. The various problems that exist are variables in determining the success or failure of learning during the COVID-19 Pandemic. These various problems should not be an obstacle. Like the policy taken by the Chinese government "Suspending Classes Without Stopping Learning" [8], the Indonesian government has also adopted a similar policy. Teachers must try to keep planning, implementing, and assessing learning as well as possible. Even though schools have not opened yet, learning must continue at various levels of education.

In online learning of course there are several weaknesses. Students' negative perceptions of online learning lead to unsuccessful learning [15]. The results of online learning are a form of culture that comes from habits [16]. Learning culture is embodied by the character of students, mastery of technology, and independent learning [17]. These three things will have an impact on learning outcomes online. In this case, online learning readiness or Online Learning Readiness Scale (OLRS) is influenced by selfdirected learning, motivation for learning, computer / Internet self-efficacy, learner control, and online communication self-efficacy [18]. There are many dimensions that need to be considered in online learning, so that learning can successfully achieve its goals.

Regarding the discussion above, vocational schools face different challenges from general schools. The mining geology expertise program is one of the vocational schools facing learning dilemmas during a pandemic. Geology is technical learning that must be done hands-on [19]. As hands-on learning, learning geology certainly cannot be just learning online via a laptop or smartphone. Vocational learning through online has many limitations compared to face-to-face learning [20]. Therefore, it is necessary to design learning that is not just online or e-learning, but also pays attention to the aspects of skills that students need to master, such as when learning hands-on. However, given the Pandemic, hands-on must still be combined with online learning. Blended learning has the potential to combine the two [21].

Blended learning is chosen as a learning system that is applied to the Fundamentals of Geology lesson. The reason for this is that blended learning is able to combine faceto-face learning with online learning in vocational education [20]. Blended gets the advantages of online learning and combines it with the advantages of face-to-face 
learning [22]. Geology has similarities with geography [23] where many studies state that blended learning has fully-succeessed in learning geography [24]-[28]. However, in reality the studies that have been carried out have not discussed field learning (practice outside the classroom) combined with blended learning. Practical learning outside the classroom in this case can be in the form of field studies, outdoor studies, or fieldwork.

Geology learning itself is characterized by fieldwork. Fieldwork is an essential activity in learning geology and geography [23]. As something essential, fieldwork must be done, especially on materials that require entry into the field, such as measuring the structure of outcrops and rock descriptions [29]. Fieldwork is a source of knowledge for students studying geology [30]. Fieldwork bridges students' understanding theoretically with reality in nature or the real world [31]. Fieldwork should be used in high intensity in geology or physical geography studies. Therefore, teachers are required to arrange fieldwork stages in accordance with the theory and conditions in the field.

There are many fieldwork models; there are at least seven fieldwork models in learning earth sciences [31]. The fieldwork models are; "teacher-centered" Model; "the field as laboratory" Model; "project-oriented" Model; "curriculum centered" Model; "technologically-enhanced" Model; "research-apprenticenship" Model; dan "reflective international fieldwork" Model [31]. As far as the researcher has read, there has never been a model that integrates fieldwork with blended learning. Including fieldwork in blended learning is a challenge in itself related to its planning, implementation in class and in the field, and how to assess geology learning.

The application of good fieldwork is made using a scientific approach. Such an approach requires syntaxes which in practice must be systematic, starting from making observations; compose questions; followed by gathering information; associate the information obtained; and ends by communicating [32]. The form of communicating in fieldwork can be a product [33]. The product of rock descriptions is rock description sheets [19], [29]. Students prefer assessments in the form of products or projects than assessments of answering questions [32]. Blended integrated fieldwork learning uses a rock description sheet in the form of a Google Form that must be filled in by students.

Integration of fieldwork with blended learning has the potential to deliver quality learning. Fieldwork can equip students with problem-solving skills, critical thinking, teamwork and emotional intelligence [31]. Before integrating blended learning and fieldwork, it is necessary to understand the characteristics of the existing subject matter. Materials that can be taught in a blinded manner in basic subjects of Fundamentals of Geology include rock [19], geological outcrops [29], and landscapes resulting from geological forces [34]. The material in the Fundamentals of Geology that has to be done with fieldwork includes those mentioned above. So in conclusion, the three materials mentioned above have the potential to be implemented in blended learning integrated fieldwork.

Another challenge in blended learning integrated fieldwork is the obligation to carry out activities in accordance with the provisions of the health protocol. The use of masks, enforcing distancing, and avoiding crowds is the basis of the health protocol that must be done during the lesson. 
Sourced from existing backgrounds, the purpose of this study is; 1) Conducting innovative learning by integrating fieldwork into blended learning; and 2) Improving student's skills in learning geology.

\section{Method}

Classroom Action Research Design (CAR) was the method used in this study. CAR was chosen because the researcher had the aim of obtaining in-depth answers to the formulation of problems in research related to planning, implementing and evaluating learning. In addition, other research methods are not as good as CAR in this respect. Apart from this, through the CAR, the effectiveness of the measures implemented can also be seen. This CAR design was based on [35]. The picture of the CAR cycle is as follows:

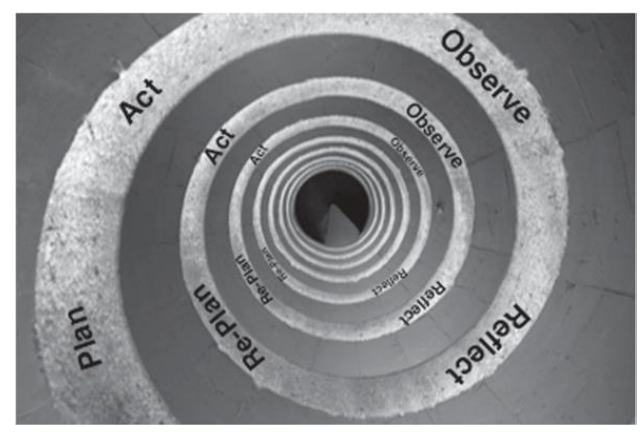

Fig. 1. CAR Cycle

Source: Kemmis et al [35]

This CAR was conducted in Class X Mining Geology at SMK Negeri 1 Binuang which consisted of 32 students. The subjects studied in this CAR is the Fundamentals of Geology with rock material. CAR was carried out for 1 (one) pre-cycle and 2 (two) action cycles. The division of each Cycle is as follows; pre-cycle with igneous rock sub-material, cycle I with sedimentary rock sub-material, and cycle II regarding metamorphic rock. The requirement for the success rate of CAR is if $75 \%$ of students complete the KKM.

Each Cycle (Cycle I and II) was carried out in four stages according to Figure 1. Each Cycle begins with planning (Plan) at the beginning, followed by action (Act), accompanied by observation (Observe); and then ends with a reflection (Reflect). Lesson Plan (RPP) in Cycle I used blended learning integrated fieldwork. The learning system was carried out by utilizing Google Classroom. The teaching materials used were in the form of video descriptions of rocks, measurements of rock geological structures, and materials in the form of PDFs from the teacher that are uploaded into Google Classroom. The assessment was carried out using a product-based assessment rubric, a rock description sheet that must be filled out by students and uploaded to Google Form. 
The action stage was carried out after the planning has been completed. This stage is used to apply the treatment (action), namely in the form of integrated blended learning fieldwork. The fieldwork steps were carried out independently by each student, but cooperation was allowed in visiting places with rock outcrops where the schedule was arranged in turns taking into account that there was no large number of student groups. Furthermore, students independently conducted rock descriptions in their respective homes with the results of the rock descriptions being filled in on the Google Form whose link the teacher had shared.

The observation stage was carried out by the teacher checking whether the students actually visited the specified location and how to find out which students took rock samples was done by looking at the photos that the students sent via WhatsApp (WA). In this stage, the teacher needs to interact online with students, so that every action taken by students can be observed by the teacher and get feedback from the teacher.

The reflection stage was carried out by the teacher, starting from assessing the product description results uploaded by students than making the percentage of students who have completed the KKM, and identifying the level of learning success. After that, the synthesis and analysis of the results obtained were carried out with a literature review. The results obtained have shown success, so that in Cycle II, in the planning stage again, the initial planning was used by changing the sedimentary rock description sheet to a metamorphic rock description sheet. The next process was to carry out the action stage, observation and reflection Cycle II.

The equipment prepared in this lesson is in the form of field geology equipment. Each student provides a loop, $\mathrm{HCl}$, and meter. The Bruton Geological Compass is replaced by the Geological Compass, an application that students can download from the Playstore. Before starting the lesson, the teacher provides directions on the importance of following health protocols, such as maintaining distance, wearing a mask, and washing hands diligently.

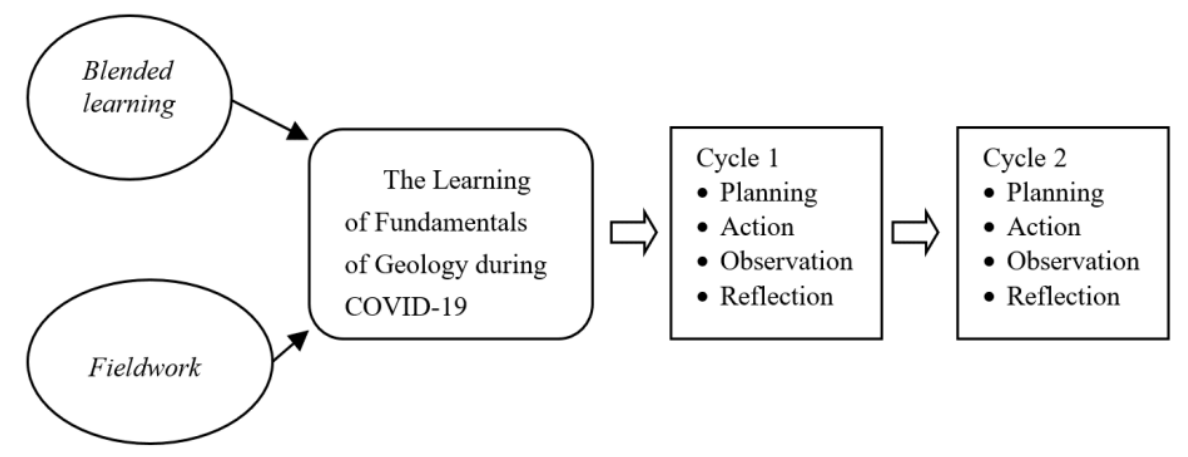

Fig. 2. Research Framework 


\section{Result and Discussion}

\subsection{Pre cycle}

Pre-cycle learning is carried out prior to action. Pre-cycle learning is carried out in response to intrusions and circulations that learning is carried out online. Online learning in the Fundamentals of Geology subject is carried out in an online mode using Google Classroom. The teacher uploaded all materials about igneous rock sub material. Meanwhile discussions and questions and answers were conducted through WA. This took into account the accessibility and habits of the students. In this case, students are still not familiar with using Google Classroom but are very familiar with WA.

The assessment was carried out using Google Assessment. This kind of assessment is also new but has been done by students. This is because students have previously used online mode assessment with other applications, but in a multiple-choice forms. The experience of students facing online exams was obtained when carrying out the Final Assessment of Semester 1. SMK Negeri 1 Binuang has been doing this online since the last few years. Meanwhile, in this lesson, students did it in the form of description questions and short answers with the Rock Description Sheet format. The percentage of students who reach the KKM in igneous rock learning can be observed in Figure 3.

Figure 3 shows that online learning has not been effective. The number of students who achieved the minimum completeness criteria (KKM) only amounted to 6 or about $18.75 \%$ of the 32 students of Class X Mining Geology, which means that less than a quarter of the students who have completed the KKM has completed. Even though in online learning, students can work on questions in an open book. This is also a special concern for teachers as researchers, is the material that has been given by the teacher through Google Classroom not read by children? Do students only enter Google Classroom to attend attendance without caring about the material? Such questions also arise along with the assumption that the willingness of children to read (literacy) is low. This pre-cycle does not pay attention to online learning readiness or OLRS which according to Hung, et. al is influenced by learning ability, motivation to learn, mastery of the internet and computers, student self-control, and online communication skills [18]. 


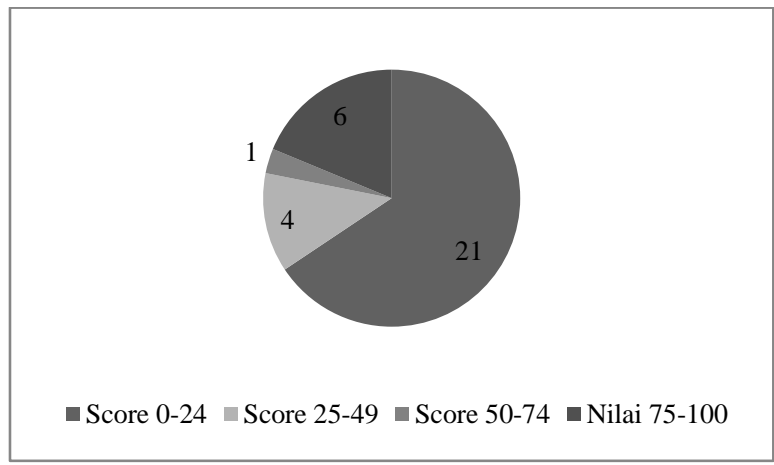

Fig. 3. Number of Students Pie Chart Based on the value obtained during the Pre Cycle

Most students tend to be passive during group WA interactions. Questions or statements that are often submitted by students to the teacher are in the form of; "Sir, I have entered the Google Classroom." or "Sir, have I been included in attendance?" Things like this illustrate that in online learning, students are only present and minimally involved in learning. In contrast to face-to-face learning, students seem to be actively reading. This could be because students' perceptions of online learning are low ([15]. Cases like this also reflect the low independence of students in learning [17]. This finding is in accordance with Bao [7] that discipline, limited mastery of the material, and an environment (home) that is not conducive during online learning will affect student learning outcomes. Students are asked to read the material in PDF form, pay attention to videos on how to describe rocks, but they don't do it which is a form of low discipline. The number of students who did not complete the KKM showed that there were limitations in mastering the material. These various problems can also be affected by conditions of the environment (home) which are not conducive where it is beyond the control of the teacher.

The findings in the pre-cycle also indicate that students in vocational schools cannot learn well if learning is only done through online learning. This confirms the results of Sahin's [20] research which states that online vocational learning has many limitations compared to face-to-face learning. In addition, the findings in this pre-cycle also strengthen the statement of Scifman, et al. which states that geology is technical learning that must be done hands-on [19]. Without hands-on learning, Mining Geology vocational school students will not find meaningful learning. The failure of online learning in the Fundamentals of Geology subject will then become the basis for improving planning for learning, implementing learning during research, and in conducting assessments in subsequent learning.

\subsection{Cycle I}

Planning: The planning made for Cycle I was the result of learning reflection, where several obstacles were found during the Pre-Cycle. Various obstacles in online learning during the Pre-Cycle give confidence that Mining Geology students must learn with 
another model, namely blended learning integrated fieldwork. The model of integrating fieldwork in blended learning has never been used by other teachers in learning the Fundamentals of Geology. This model is a new innovation. This model was developed because if it only uses online learning, students cannot acquire geology skills in the field. This lesson plan contains the steps for integrated Blended learning Fieldwork. The rock description sheet on Google Form must also be a photo of the rock taken directly in the field, not just a rock image taken from the internet. The effort to use fieldwork is to ensure that students learn hands-on at the planning stage of Cycle 1.

Act: The steps at this stage are; First, students go to the field (location of outcrop) of sedimentary rocks that have been determined by the teacher (based on a schedule arranged to prevent the gathering of people). Second, students then formulated questions about the descriptions of the rocks they took in the field. Third, students collect information about the rocks they get. Fourth, students synthesize data and information. In this fourth step, there is a synthesis of information and analysis of information that must be done in the field, such as measuring strike and dip, as well as the thickness of the rock layers, but there is also something done at home such as identifying rock samples with loops, and giving $\mathrm{HCl}$ to rocks to determine the levels. Fifth, students communicate the results of their descriptions through the Google Form rock description sheet and send (submit) to the teacher.

Observation:Observations were made through photos sent by students. Observational data show that some students do not wear safety shoes and safety helmets (according to the Health and Safety provisions that mining geology teachers always convey when working in the field). During this Pandemic, many students still do not wear masks when they go to the field. The other side shows that students enjoy learning in the field hands-on. The results of the rock descriptions sent were also good. Meanwhile, the rock description assessment shows the results, as shown in Figure 5.

Students still have difficulty using the Geological Compass in the form of an application. Students prefer the Bruton Geological Compass, which they usually use. There were still students who were absent in the lesson, so they were given a score of 0 by the teacher. There are students who do not go to the field (because they do not send selfies in the field) but send a rock description sheet from the Google Form, so that they are given a score of 25. Students who do not wear Personal Protective Equipment (PPE), namely helmets and safety shoes are given a low score of 75 .

Scheduling that is done within a day seems to be difficult for students. It has been tried to find the fieldwork location that is closest to the student's residence, but there are still students who get lost heading to the location so that they are late in collecting assignments. The selected rock sampling location (outcrop) is an area that can still be reached by internet signals, so that the teacher has the opportunity to guide students when they make observations. However, there are locations that cannot be used for video calls; this is the finding of an obstacle, namely that it is difficult to provide directions to students. 


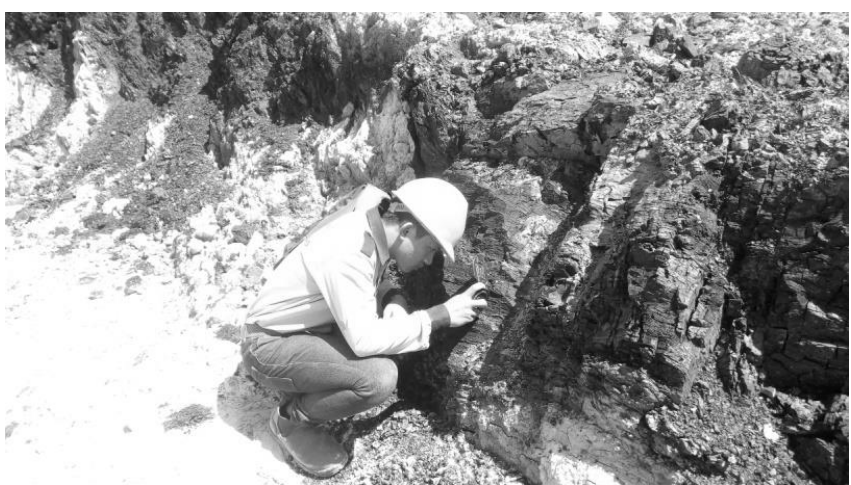

Fig. 4. Students Measuring Strike and Dip with the Geological Compass Application

Most of the students in Cycle I carried out learning and assessment well. This can be observed in Figure 4. In the picture, it can be seen that 27 students out of 32 students have completed the description of sedimentary rocks. Cycle 1 can be said to be successful, because $84.375 \%$ of students scored above the KKM. The results obtained exceed the stipulated provisions, which are based on the figure that $75 \%$ of students complete the KKM. This data implies that blended learning integrated fieldwork is effective for use in learning the Fundamentals of Geology.

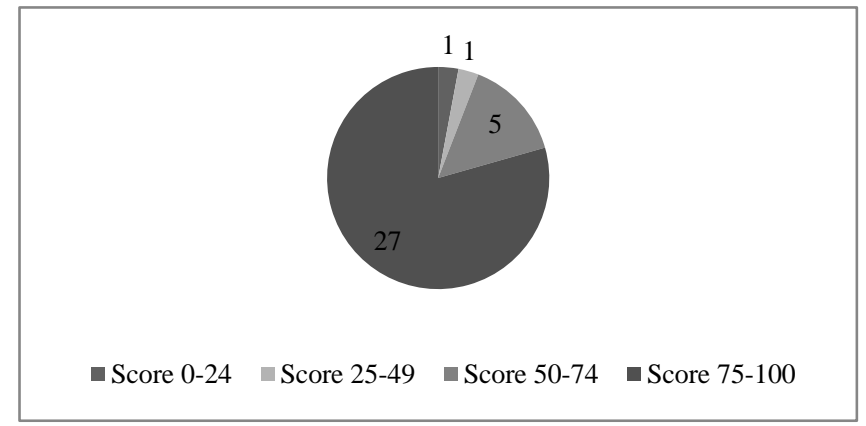

Fig. 5. Number of Students Pie Chart Based on the value obtained during Cycle II

Reflection: Reflection is carried out through synthesis and analysis of findings from the previous three stages. This success is due to several factors, including the rock material that is suitable for blended and fieldwork. This is like geography which has a great chance of succeeding with the use of blended learning [24]-[28]. Geology also has success because geography and geology are both similar [23]. Fellow earth sciences, these two branches of science can be studied by blended learning.

Fieldwork provides students with hands-on learning experiences. Geology is a science that is suitable to be studied in fieldwork because this is indeed a feature of this science [23]. Through fieldwork, students can do rock description better than just 
learning online. This is in accordance with what was stated by France \& Haigh [31] which states that fieldwork can bridge theory and reality in nature, whereas studying geology online alone cannot do this. This finding also confirms the statement of Barros, et al. [13] which states that fieldwork is a good source of knowledge for students studying geology.

\subsection{Cycle II}

Planning: The first stage carried out in Cycle II is not much different from the planning in the previous Cycle. This is done because seeing the success obtained in Cycle I. Cycle II is only an effort to strengthen opinions about the ability of blended learning integrated fieldwork in learning the Fundamentalss of Geology. The fundamental thing that was replaced was the determination of the location of the fieldwork, because the location of the sedimentary rock outcrop (in Cycle I) was not the same as the location of the metamorphic rock outcrop (in Cycle II). The scheduling was also carried out longer by considering various conditions, one of which was the number of locations that had metamorphic rock outcrops which were not as many as sedimentary rock outcrops.

Act: In the second stage in Cycle II, which is in the form of treatment, it is also not much different from the action stage in Cycle I. Students still have to do fieldwork with the scientific stage. Students must also send photos / videos while in the field, when taking rock samples, and when describing rocks. The format of the metamorphic and sedimentary rock description sheets is different, but the teacher has sent the material in PDF form in the Google Classroom, so that students can study it beforehand.

Observation: There are still students who do not use PPE when working in the field. This is actually a fatal mistake in implementing geology learning in the field. Not using PPE means that students ignore K3. Some students also do not wear masks. These two things are a serious concern of the teacher. The teacher still reprimands students who ignore PPE and masks. This was done because the research focused on the application of blended learning integrated fieldwork. Therefore, the safety of students when carrying out fieldwork is also a concern of teachers.

The location of the metamorphic rock outcrops is far from the village and some of them cannot reach the internet signal. This is what makes the teacher and student communication constrained. Students who should do a description of metamorphic rocks are doing a description of sedimentary rocks. However, this can be corrected when students arrive home and already have an internet signal for communication, so that this problem can be temporarily resolved.

As many as 11 students were declared not fulfilling the KKM because they did not do fieldwork in the field. The students argued that the location of the metamorphous rock outcrops was far from their homes and their parents were not allowed to go there. This kind of thing has not been anticipated by teachers in planning blended learning integrated fieldwork. However, as many as 21 other students $(77.78 \%)$ carried out fieldwork well, even though they were constrained by communication signals when they were in the field. 


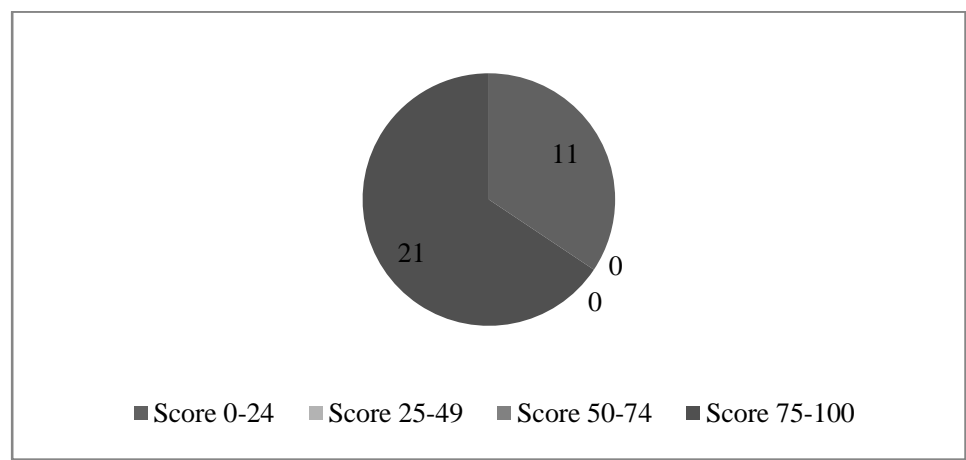

Fig. 6. Number of Students Pie Chart Based on the value obtained during Cycle I

Reflection: Some students completed KKM during Cycle II. Students who are not in accordance with the KKM are because they do not carry out fieldwork on the grounds that they are far from home and do not get parental permission so that the teacher needs to replace it with another assignment. However, what should be noted here is that determining the location of the fieldwork must be carefully planned, it is necessary to contact parents to get permission, and it is necessary to anticipate other things that might hinder the fieldwork such as the difficulty of finding an internet signal for communication.

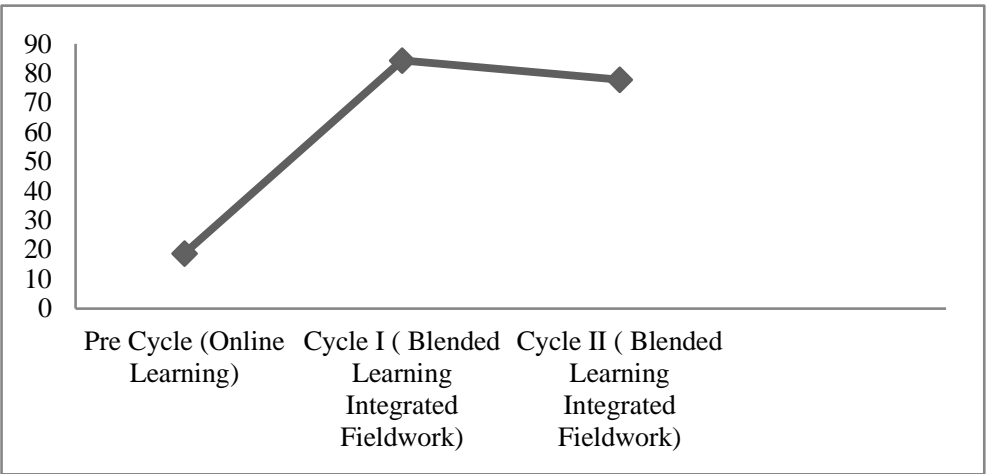

Fig. 7. Percentage Graph of Total Students Completing KKM During Pre Cycle, Cycle I, and Cycle II

The percentage of students who completed the KKM during Cycle II, although not as high as Cycle I, showed very significant success. This is indicated by more than $75 \%$ of students who complete. This shows that blended learning integrated fieldwork is effective for use in Fundamentals of Geology learning during the COVID-19 Pandemic. Fieldwork using scientific learning steps is able to equip students with problem-solving skills, critical thinking, teamwork and emotional intelligence as argued by France \& Haigh [31]. This is also because the fieldwork carried out is carried out in a scientific 
approach is according to Oktavianto's suggestion [34] and uses product testing [33]. Fieldwork is indeed more appropriate to product test assessments than written exams.

\section{Conclusion}

Based on the findings discussed in the results and discussion above, it can be concluded that the integration of fieldwork with blended learning is effective in presenting quality learning seen through the number of students who completed. Cycle I shows that $84.374 \%$ of students have completed the KKM, while in Cycle II, $77.78 \%$ of students have completed the KKM. The number of students who completed the KKM even though it decreased from Cycle I to Cycle II but still showed completeness above $75 \%$ so it could be said that the method used was successful. This also shows that blended learning integrated fieldwork is effectively used in learning the Fundamentals of Geology during the Pandemic.

Blended learning integrated fieldwork is carried out by eliminating face-to-face learning, but students are still required to carry out hands-on learning. This model is also suggested to use a scientific approach. During fieldwork learning, as much as possible the teacher should communicate with students.

Suggestions for researchers or other teachers who will use blended learning implanted fieldwork are to ensure that the fieldwork location is accessible to students and communication signals and the internet can be reached. This is important because it can help teachers provide guidance intensively. Regarding the problem of the COVID-19 Pandemic, it is necessary to carefully and precisely compile an integrated blended learning fieldwork learning guide according to the health protocol considering that in this study there were still students who neglected the use of masks.

\section{$5 \quad$ References}

[1] R. M. Viner et al., "School closure and management practices during coronavirus outbreaks including COVID-19: a rapid systematic review," The Lancet Child and Adolescent Health, vol. 4, no. 5, pp. 397-404, 2020. https://doi.org/10.1016/s2352-4642(20)30095-x

[2] F. Reimers and A. Schleicher, "A framework to guide an education response to the COVID19 pandemic," 2020. doi: 10.3102/00346543066003227.

[3] E. J. Sintema, "Effect of COVID-19 on the Performance of Grade 12 Stu-dents: Implications for STEM Education," Eurasia Journal of Mathematics, Science and Technology Education, vol. 16, no. 7, pp. 1-6, 2020. https://doi.org/10.29333/ejmste/7893

[4] S. J. Daniel, "Education and the COVID-19 pandemic," Prospects, no. 0123456789, 2020, doi: 10.1007/s11125-020-09464-3.

[5] J. Michael McWilliams, "Professionalism Revealed: Rethinking Quality Improvement in the Wake of a Pandemic," NEJM Catalyst, no. 5, 2020. https://doi.org/10.1056/cat.20.0226

[6] C. Hodges, S. Moore, B. Lockee, T. Trust, and A. Bond, "The Difference Be-tween Emergency Remote Teaching and Online Learning,” Educause review, p. 7, 2020.

[7] W. Bao, "COVID -19 and online teaching in higher education: A case study of Peking University," Human Behavior and Emerging Technologies, vol. 2, no. 2, pp. 113-115, 2020. https://doi.org/10.1002/hbe2.191 
[8] W. Zhang, Y. Wang, L. Yang, and C. Wang, "Suspending Classes Without Stopping Learning: China's Education Emergency Management Policy in the COVID-19 Outbreak," Journal of Risk and Financial Management, vol. 13, no. 3, p. 55, 2020. https://doi.org/10.3390/jrfm13030055

[9] C. Wang, Z. Cheng, X.-G. Yue, and M. McAleer, "Risk Management of COVID-19 by Universities in China," Journal of Risk and Financial Management, vol. 13, no. 2, p. 36, 2020. https://doi.org/10.3390/jrfm13020036

[10] L. Schrum and S. Hong, "Dimensions and strategies for online success: Voices from experienced educators," Journal of Asynchronous Learning Network, vol. 6, no. 1, pp. 57-67, 2002. https://doi.org/10.24059/olj.v6i1.1872

[11] K. P. King, "Identifying success in online teacher education and professional development," Internet and Higher Education, vol. 5, no. 3, pp. 231-246, 2002. https://doi.org/10.1016/s1096-7516(02)00104-5

[12] G. Basilaia and D. Kvavadze, "Transition to Online Education in Schools during a SARSCoV-2 Coronavirus (COVID-19) Pandemic in Georgia," Pedagogical Research, vol. 5, no. 4, 2020. https://doi.org/10.29333/pr/7937

[13] R. Brightwell, J.-H. Daniel, and A. Stewart, "Evaluation: is an open book ex-amination easier?" Bioscience Education, vol. 3, no. 1, pp. 1-10, 2004. https://doi.org/10.3108 /beej.2004.03000004

[14] D. Glenda and C. Rakes, "Open book testing in online learning environments," Journal of Interactive Online Learning, vol. 7, no. 1, pp. 1-9, 2008.

[15] B. Todhunter, "LOL - limitations of online learning - are we selling the open and distance education message short?" Distance Education, vol. 34, no. 2, pp. 232-252, 2013. https://doi.org/10.1080/01587919.2013.802402

[16] X. Liu, S. Liu, S.-H. Lee, and R. J. Magjuka, "International Forum of Educational Technology \& Society Cultural Differences in Online Learning: International Student Perceptions," Source: Journal of Educational Technology \& Society, vol. 13, no. 3, pp. 177-188, 2010, doi: 10.2307/jeductechsoci.13.3.177.

[17] C. H. Wang, D. M. Shannon, and M. E. Ross, "Students' characteristics, self-regulated learning, technology self-efficacy, and course outcomes in online learning," Distance Edu-cation, vol. 34, no. 3, pp. 302-323, 2013. https://doi.org/10.1080/01587919.2013.835779

[18] M. L. Hung, C. Chou, C. H. Chen, and Z. Y. Own, "Learner readiness for online learning: Scale development and student perceptions," Computers and Education, vol. 55, no. 3, pp. 1080-1090, 2010. https://doi.org/10.1016/j.compedu.2010.05.004

[19] L. Schifman et al., "Sleuthing through the rock cycle: An online guided inquiry tool for middle and high school geoscience education," Journal of Geosci-ence Education, vol. 61, no. 3, pp. 268-279, 2013, doi: 10.5408/12-326.1.

[20] M. Sahin, "Blended learning in vocational education: An experimental study," International Journal of Vocational and Technical Education, vol. 2, no. October, pp. 95-101, 2010.

[21] P. J. Samson and P. J. Samson, "Student behaviors in a blended synchronous course Student behaviors in a blended synchronous course," Journal of Geoscience Education, vol. 0, no. 0, pp. 1-10, 2020. https://doi.org/10.1080/10899995.2020.1768002

[22] I. Clark and P. James, "Blending what? An approach to delivering earth science courses online," International Journal of Innovation in Science and Mathematics Education (formerly CAL-laborate International), vol. 14, no. 1, 2012.

[23] A. Stokes, K. Magnier, and R. Weaver, "What is the use of fieldwork? Conceptions of students and staff in geography and geology," Journal of Geography in Higher Education, vol. 35, no. 1, pp. 121-141, 2011. https://doi.org/10.1080/03098265.2010.487203 
[24] Y. Dikmenli, "Effect of the blended learning environment and the application of virtual ÜlküEserÜnaldi," Mevlana International Journal of Education (MIJE), vol. 3, no. 2, pp. 4356, 2013. https://doi.org/10.13054/mije.13.26.3.2

[25] S. McPhee and G. Pickren, "Blended learning with international students: a multiliteracies approach," Journal of Geography in Higher Education, vol. 41, no. 3, pp. 418-433, 2017. https://doi.org/10.1080/03098265.2017.1331208

[26] P. Mitchell and P. Forer, "Blended learning: The perceptions of first-year geography students," Journal of Geography in Higher Education, vol. 34, no. 1, pp. 77-89, 2010, https://doi.org/10.1080/03098260902982484

[27] A. Godlewska et al., "Converting a large lecture class to an active blended learning class: why, how, and what we learned," Journal of Geography in Higher Education, vol. 43, no. 1, pp. 96-115, 2019. https://doi.org/10.1080/03098265.2019.1570090

[28] N. Moore and M. Gilmartin, "Teaching for better learning: A blended learning pilot project with first-year geography undergraduates," Journal of Geography in Higher Education, vol. 34, no. 3, pp. 327-344, 2010. https://doi.org/10.1080/03098265.2010.501552

[29] J. Pringle, A. Gardiner, and R. Westerman, "Virtual geological outcrops - Fieldwork and analysis made less exhaustive?" Geology Today, vol. 20, no. 2, pp. 67-71, 2004, https://doi.org/10.1111/j.1365-2451.2004.00450.x

[30] J. F. de Barros, P. A. Almeida, and N. Cruz, "Fieldwork in Geology: Teachers' Conceptions and Practices," Procedia - Social and Behavioral Sciences, vol. 47, pp. 829-834, 2012. https://doi.org/10.1016/j.sbspro.2012.06.743

[31] D. France and M. Haigh, "Fieldwork@40: fieldwork in geography higher education," Journal of Geography in Higher Education, vol. 42, no. 4, pp. 498-514, 2018, https://doi.org/10.1080/03098265.2018.1515187

[32] D. A. Oktavianto, "Pembuatan Model Pembelajaran Google Earth UntukMeningkatkan Hasil Belajar Pemetaan Geologi," 2019.

[33] D. A. Oktavianto, Sumarmi, and B. Handoyo, "Pengaruh Pembelajaran Berbasis Proyek Ber-bantuan Google Earth terhadap Keterampilan Berpikir Kritis the Effect of Project-Based Learning Assisted Google Earth to Spatial Thinking Skills," Jurnal Teknodik, vol. 21, no. 1, pp. 1-15, 2017.

[34] D. A. Oktavianto, "Groups Investigation Learning Model to Analyze the Landscape Effect of Geological Processes Using Google Earth,” Teknologi Pendidikan, vol. 23, no. 1, pp. 1$14,2019$.

[35] S. Kemmis, R. McTaggart, and R. Nixon, The Action Research Planner: Doing Critical Participatory Action Research. Springer Science \& Business Media, 2013. https://doi.org/10.1007/978-981-4560-67-2 5

\section{Authors}

Dwi Angga Oktavianto is postgraduate students, Departement of Geography, Universitas Negeri Malang, Malang, Indonesia and a teacher of Geoscience on SMK Negeri 1 Binuang, Tapin, Indonesia.

Sumarmi is a professor, lecturer, and researcher at Department of Geography Education, Faculty of Social Science, Universitas Negeri Malang, Indonesia. Field of expertises are in environmental geography, geography learning, and environmental education based on local wisdom. 
Sugeng Utaya is a professor, lecturer, and researcher at Department of Geography Education, Faculty of Social Science, Universitas Negeri Malang, Indonesia. Field of expertises are in physical geography, hydrology, and environmental geography.

Didik Taryana is a senior lecturer, and researcher at Department of Geography Education, Faculty of Social Science, Universitas Negeri Malang, Indonesia. Field of expertises are in physical geography, and geomorphology.

Article submitted 2021-01-12. Resubmitted 2021-02-21. Final acceptance 2021-02-24. Final version published as submitted by the authors. 